\title{
ETHNIC AND RELIGIOUS IDENTITY IN THE SOCIALIST FEDERAL REPUBLIC OF YUGOSLAVIA
}

Abstract: Socialism as a political system, based on the supreme authority of the party, and relying on collectivism, tried to wipe away every difference between the social groups in the SFRY. Marxist ideology had a generally negative attitude towards religion, which led to the weakening of the religious identity in the population of Yugoslavia. On the other hand, the creation of the Yugoslav nation obstructed the development of the ethnic identity to a large extent. Consequently, the state identity was maximally intensified in the citizens of the SFRY. An above-national society with no state religion was formed. With this, the principles of ethnic and religious tolerance were practically implemented, relying on the brotherhood and unity of the peoples and nationalities, as its highest ideals.

Keywords: ethnic identity; religious identity; state identity

\section{Introduction}

In the social system of the Socialist Federal Republic of Yugoslavia, there existed many ethnic groups that shared their destinies and carried the elements of communal life. Yugoslav nations and ethnic groups have had common victories and defeats in many important moments of their history. Consequently, they share a cult towards their common ancestors. Furthermore, especially in the context of Christianity, they celebrate many of the same saints, whom they pray to and celebrate together. This acted as a form of a strong spiritual backbone for these different religious and ethnic identities in the moments of social crises. Because they lived in the same country, they had the same political fate. This created ethnic and religious collectives with common histories, which had a strong influence on strengthening the feeling of common origin. This sometimes provides that last and crucial thread of belonging to the national consciousness (Weber, 1963). However, despite all this, these ethnic communities have kept their own national identity. The fact that they were united in their fight against the fascist regime certainly influenced this. Consequently, they lived together for a long time in the same political system and they

\footnotetext{
1 matev@mt.net.mk

2 dmatevska@hotmail.com
} 
created and implemented a communist system, different from other systems in the context of a socialist communist system, which is again different from other in the context of a socialist self-government (Giddens, 2007).

To understand all this, we have to highlight certain cultural and political characteristics of the Yugoslav state. From a historical point of view, Yugoslavia was burdened by an authoritarian political culture. The strong and long-lasting domination of foreign powers and empires (such as the Ottoman Empire, the Austro-Hungarian Empire, etc.) left their mark on all political, ethnic and religious events and relations. The citizens of the SFRY lived at a time marked by the clash of the authoritarian political culture, on the one hand, and the socialist political culture on the other. The way in which the religious and ethnic relations in the SFRY unfolded greatly depended on the outcome of this epochal collision. The indication of a parallel existence of these elements of authoritarian and socialist political cultures is exceptionally important in the genesis of these relations, which would later turn into bloody open conflicts during the breakdown of Yugoslavia. The ex-Yugoslav republics are rather heterogeneous in an ethnic, religious and cultural way (Ćebic, 1988). In all this diversity, we should not underestimate the religious element, which is deeply rooted, which has tradition and which divides the population in separate religious groups. Namely, the tradition of all three religions in the ex-Yugoslav region (Orthodoxy, Catholicism and Islam) is to rely on the elements of authoritarian action. All this has had an effect on society as a whole.

Social identity implies group self-categorization and a self-identification of the individual, with certain stereotypes about other religious and ethnic groups that are different. The term collective identity is tightly linked to the disappearance of personality and individuality in bigger structures. Each individual tries to create his or her own personal identification. Without it, they feel lost in time and space. There exist various mechanisms of personal identification. For the purposes of this analysis, we will focus on three, in our opinion, most important mechanisms of personal identification. These are ethnic, religious and national (civil) personal identifications. All these mechanisms of personal self-identification cannot exist with the same intensity. The strengthening of one necessitates the weakening of another. The question we will try to answer is which mechanism of personal identification was most important and most intense in the citizens of the SFRY?

\section{Ethnic identity in the SFRY}

Different ethnic and religious groups in the SFRY always felt a need to differentiate themselves from the others. With the answer to the questions of identity, individuals strived to find out how they were different from the religious and ethnic other. Identity is tightly linked to the feeling of security, trust and belonging to a certain religious or ethnic group. However, the strive to incorporate and preserve this identity prompted the citizens of the SFRY in certain situations to act irrationally and sometimes even violently. In the conditions of ethnic and religious diversity, in an attempt to answer the question of belonging, individuals first attach themselves to their ethnic and religious origin. In ethnically mixed environments, the identity of an individual is largely linked to their belonging to linguistically, culturally and religiously determined communities. The ethnic identity, more than any other identity, is a product of primary socialization. Ever since early childhood, 
individuals learn the differences between "us" and "them" and to not accept anything that comes from "them" so easily. This process can happen spontaneously and peacefully, but can also be followed by tension and conflicts, especially when "they" impose their identity on "us". This tense situation represents one of the main reasons behind the appearance of ethnonationalism in the SFRY. This is a doctrine which an ethnic group sets as a goal for every political activity, while the ethnic identity is set as a measure for every human value. Ethnonationalism becomes a power that attracts individuals and groups because it is a doctrine empowered by ethnic myths, heroes and a common destiny. With those individuals and groups where the ethnic and religious identity hadn't been burdened by ethnonationalism, it represented a cultural tradition which didn't pressure nor confine. On the other hand, to certain political structures and elites in the SFRY, ethnonationalism was basically a way to manipulate, which would ultimately lead to the breakdown of Yugoslavia.

At the time, identity strengthened the process of unifying the personal and the collective, and represented a way of finding one's own personal identity in the context of the collective. Since a person belongs to different social groups, which define their identity, then the identity gained different group and collective dimensions. The personal dimension of the collective identity made it possible to legitimately talk and act in the context of the nation and religion. National identities were based on common myths and historical memories, common mass culture, common rights and duties for all members of the common economy, with territorial mobility of its members (Smith, 1991, p. 14). Despite the external functions of the national identity, many of its internal functions were established, such as the socialization of individuals as members of the national entity and the citizens of the SFRY.

The ethnonationalism in the SFRY manifested itself as an overdependence of individuals to their nations and their interests, disregarding the interests of the other nations which were determined as friendly in certain historical and social contexts and hostile in others. It appeared as a form of national consciousness which constantly emphasized the differences between one's own and other nations, representing one's own as superior to all others. This led to an expression of prejudice with regard to other ethnic groups and doubt in their intentions. Parallel to this was a perpetual devaluation of cultural creations and characteristics of other nations in their immediate surroundings. Everyone strived to achieve the privileged position in the context of the Yugoslav federation (Žunic, 2008).

The instrumentalization of the ethnic identity through ethnonationalism manifested itself through many ethnic conflicts in the SFRY, especially in the 1970s and 1980s. That was of course further strengthened by the processes of economic, political and cultural globalization. At that time, slowly but surely, the process of transition from one model of government and socio-collectivist paradigm (socialism) to a completely different model, such as political pluralism in the context of liberal capitalism, was started. All this has led to a new socio-interactive template of behavior wherein ethnonationalism has imposed itself as a mobilizing and homogenizing resource. That process unfortunately pushed out the previous policy of brotherhood and unity which was a symbol of ethnic and religious tolerance. The kindling of ethnonationalism and national exclusivism overpowered the idea of the coexistence of various ethnic groups, which had been the dominant social value in the previous period and the foundation of a peaceful resolution and management of ethnic and religious conflicts. 
One of the main reasons for the conflicts in the SFRY in the 1990s was the manipulation of the national question, where different social, economic, cultural and political questions turned into problems centered around the national one, which represented an ethnicization of the political and a politization of the ethnic question. The ethnonationalist discourse is founded on the historic past, tradition, customs and oral tradition. The basic and most important identity in ethnonationalism is the ethnic identity. It is determined, given, inherited and cannot be changed. The ethnic identity largely determines the other identities. Above all, it determines the religious identity. One of the fundamental problems related to ethnonationalism in the SFRY was the overlap of ethnic and religious identities. To define their own identity, the ethnic groups in the territory of ex-SFRY used cultural characteristics, symbols and myths which can be found in large amounts in Orthodox, Catholic and Muslim religions. For that reason, as a rule, a large majority of ethnic Serbs, Macedonians and Montenegrins declared themselves as Orthodox, while most ethnic Croats and Slovenes declared themselves as Catholics. Even a large part of the atheists weren't exempt from this rule (Bogomilova, 2005).

The process of overlapping Islam with ethnicity was unique and intriguing. In the census of the Yugoslav population in 1948, the population of Bosnia and Herzegovina was given 3 options regarding their nationality: Muslim Serb, Muslim Croat or Muslim with an undetermined nationality. The result was that 25,000 chose Muslim Croat, 72,000 chose Muslim Serb and 778000 declared that they were of an undetermined nationality. The census of 1953 was the last time questions related to religion were asked. Then, in all of Yugoslavia, 12.5\% declared themselves as being Muslims. At the time, the term Muslim had only a religious meaning. In the context of the idea to establish the category Yugoslav as an ethnicity, the category Muslim-with an undetermined nationality appeared on the census. In Bosnia and Herzegovina, 891000 declared themselves as such. From the census of 1971, the term Muslim gained a national connotation again (Malcolm, 1994). Because of this, the largest part of the population declared to be ethnically Yugoslav lived and worked in Bosnia and Herzegovina.

Unlike in the other parts of the SFRY, in Bosnia and Herzegovina, ethnic and religious Muslims overlap, because only here do they form one ethnonational category. It is a fact that even before the Islamization, the population of Bosnia and Herzegovina didn't have a unified Serbian or Croatian identity. If we judge the complex religious, cultural and historic legitimacy of the Bosnian Muslims, they have expressed a clear demand for an ethnic identity which differs from the Serbs and Croats. They have identified themselves as members of the formed Muslim culture, which was accepted several centuries ago, more or less voluntarily in the capacity of Slovenes under the Ottoman rule. Furthermore, people who did not belong to the Muslim community and did not practice their faith also joined the Muslim nationality.

Muslims determined their own ethnonational identity and started to declare themselves as Bosnians in a national sense more often. With that, the political elite in Bosnia and Herzegovina wanted to prove that Bosnian people existed, i.e. the Bosnian ethnic group, which differs from the Serbian and Croatian ethnic group. The legitimization of the Bosnian identity imposed a serious of questions, which among other things, only illustrate the complex cultural tradition of the SFRY. Does the determination Bosnian relate to all inhabitants of Bosnia and Herzegovina or just to the Muslims? What kind of relations do 
the Bosnians have with other Islamized Slovenes in the SFRY, such as the Macedonian Muslims in Macedonia? This clearly points out that, in the ethnocultural mixture in the SFRY, there were no clear ethnic solutions.

\section{Religious identity in the SFRY}

The geopolitical position of the SFRY was such that, even during the so-called Great Schism in the $11^{\text {th }}$ century, the borders between the Eastern (Byzantine) and the Western (Roman) Churches were crossing the territory of the SFRY. The situation fundamentally changed, becoming even more complex, in the $15^{\text {th }}$ century, when a large portion of the territories that later became a part of the SFRY were annexed by the then mighty Ottoman Empire. From then on, three distinct types of civilization went together with the three types of religion: Catholicism, Orthodoxy and Islam. In the territory of the SFRY, three kingdoms of heaven (Catholicism, Orthodoxy and Islam) came into contact and intertwined. Consequently, it has been a battleground of three great cultures and civilizations. Europe, especially in the beginning of the Middle Ages, was shaped by the ancient authentic values of Judaism, Christianity and Islam. Not far from there, in Macedonia, Bulgaria and Bosnia and Herzegovina, there were secret groups of Bogomilism, active in those regions for several centuries. All these religions are very similar to one another in their cores, because they originate from Judaism as their common ancient foundation. Furthermore, all of them preach peace as their ideal. Despite this, the SFRY was faced with interreligious disputes that later turned into bloody conflicts during the breakdown of the SFRY through a harsh and merciless abuse of the religious feelings of the citizens of the SFRY.

This, above all, results from the essence of the great monotheistic religions that emerged from the Abrahamic tradition. At their core, they are very intolerant. They have solidified and unchangeable worldviews, a strict ethical codex and they draw a clear border between those who are and those who are not true believers. Their dogmas and rules are said to have been given by god and are eternal truth. They cannot be subject to negotiations, compromise or concessions. When one such group is faced with another similar group, they inevitably declare each other as heathens, heretics and apostates. They are not able to admit each other's share in knowing the truth. To do that would be to throw doubt on their own dogmas. When the believers of these three religions step into contact, they usually end in conflict. These religions are, at the same time, very collectivistic. They claim that their believers create a special and morally superior community. The connections with them easily become a sign of a political or national loyalty. The biggest danger lies in the connection between a nation and religion. Moreover, if Abrahamic religions become factors in politics, they lead to eternal conflict with the religious other due to their uncompromising views (Heywood, 2009).

Now, in the context of the subject, we will talk about the relationship between religion and nation. To begin, we need to emphasize the irrefutable fact that both religion and nation are two powerful forms of belonging and identification. They are powerful mechanisms through which a person searches for their own identity. Nevertheless, these two forms of identity cannot have the same intensity at any one time. To strengthen the national feeling, the religious one needs to be weakened and vice versa. The majority of 
sociological research studies in this domain point to an interesting piece of data. Religion and nation have no logical connection. In addition to this is the fact that faith is a universal category above nation. However, despite these irrefutable facts, these two social phenomena are in an indestructible psychological connection and secret union. Religious intolerance is especially heightened in times of ethnic conflict. Only then do faith and nation become the same thing. In all other peaceful times, that is not the case (Ramet, 2008).

From all this we can conclude that people and nations are historical facts, while faith is beyond history and an eschatological category. For religion, and church as her institution, the most important thing is the person or the believer, while the spirit of belonging is most important for the nation. If we try to make a certain distinction between nation and religion, then we can say that temporally speaking, religion precedes nation. The existence of religion is linked with the very appearance of man, while nations have only existed for the past 2 centuries. Secondly, religion is a more important classifier than nation because it is more general. If you want to point out that someone is a good person you would say that he or she is a good Christian or a good Muslim. The expression "good believer" points to a morally perfect person. Thirdly, from an ethical point of view, religion is above nation. Religion is an ethical category, while nation is an ethnic category. We will conclude this part with the statement that equality of religious institutions and groups gives a better chance of cohesion and integration of the social community (Davie, 2017). Similarly, the idea of forming a single state religion reduces the chances that all segments of social life would be integrated. Consequently, we could state that in the SFRY there were never religious conflicts, only ethnic conflicts encouraged by political goals.

The best way to establish religious and ethnic tolerance as well as the idea of ecumenism and neo-ecumenism is to create an above-national society. In this above-national society, the only criterion is citizenship. In that type of society, human values become more general. The generalization of values and norms goes up to forming universal human rights and values. This brings the fall of the inherited ethnic rights and their associated customs, moral norms and precepts. The universal values and norms, as well as their associated human rights and liberties apply to the entire population of said society, which is not the case in ethnic communities. All this was established in the SFRY through the idea of brotherhood and unity. The system of values and norms was elevated to a universal plane. The case of the SFRY confirms that, as there is a process of separation of the church and the state, similarly, there is such a process for separating citizenship and nationality.

The phenomenon of religious other, i.e., alterity, became the highest priority for the socialist Yugoslav society. The communist political elite of the SFRY could not neglect, much less ignore, this phenomenon. The brotherhood and unity as a political ideology was based on the idea that the citizens of the SFRY should respect one another despite their religion and ethnicity. In the multiethnic and multiconfessional environments in every autonomous republic and province of the SFRY, people were instructed to communicate and live with one another. Through the ideas of brotherhood and unity, people were taught that another's religious identity does not threaten them in any way, but on the contrary only enriches them and their own religious identity. The Yugoslav federation survived on the basis that the system of socialist self-government was created by everyone equally, despite their religion and ethnicity. All else was prejudice, which during certain 
periods of the development of the Yugoslav socialist society couldn't be overcome, or was needlessly emphasized. All this led to ethnic and religious conflicts, especially during the breakdown of Yugoslavia.

The ideologues and the political elite of the socialist political system in the SFRY knew that religious otherness is a very sensitive phenomenon. From a theoretical point of view, ethnic and religious otherness is a constitutive category, i.e., a problem of interaction between two people, between two statements, or a problem of spatial and temporal communication between two or more cultures, as was rightfully emphasized by one of the greatest contemporary anthropologists and sociologists Claude Lévi-Strauss. This phenomenon of the ethnic and religious other was explicitly established in the most sensitive spheres of social life, in education, politics and mass media. The children, in all of educational institutions of all republics and provinces of the SFRY, learned about the practical benefits of respecting the ethnic and religious other.

In this analysis, we are trying to elaborate on the problem of closedness of small organic cultures. When we talk about the SFRY, we are talking about cultures that have always clashed and were faced with potential misunderstandings. The eventual conflicts were solved by "euphoria of closedness", dividing the subjects between 'us' and 'them', such that it is known beforehand who belongs to which group. This type of culture surrenders itself to its own airtightness, living the illusion that everything that is not 'ours' is unnatural. Our analysis of the factual status of all types of otherness represented in education, politics and mass media in the SFRY offers arguments which prove that the distrust, closedness and isolationism were not only unnatural for the Yugoslav socialist society, but were completely unattainable as existential categories in the larger sphere of everyday life. All this was realized through a practical implementation of the principles of ethnic and religious tolerance, expressed through the idea of brotherhood and unity between all peoples and ethnic groups in the SFRY.

For the longest time in the social development of the SFRY, the principles of tolerance were accepted under the so-called model of communal living of different communities with different cultures and religions. In the SFRY, there were several religious communities and religious groups that showed an interest in keeping and nourishing their cultural and historic heritage. This was expressed by a resistance towards that which was "alien and not mine" or which belonged to "them" and not "us". Consequently, the question of developing a consciousness and methodology that would make the sharing of religious heritage over the entire territory of the SFRY possible was raised. The representation of the other, his or her naming and recognizing by another religious group depend on the point of view of the subject. For instance, for an Orthodox Christian, the other is a Muslim, a Catholic, a Protestant or a member of any new religious movement.

Everything that has been created on territory of the Yugoslav Federation through the ages by different cultures and civilizations should not be negated, but cherished, objectively treated and studied and accepted as joint cultural heritage. The questions that were raised in this context were treated seriously and elaborated by the Communist Party of Yugoslavia. Many congresses and plenums organized by the CPY were dedicated to the development of the principles of ethnic and religious tolerance expressed through the ideas of brotherhood and unity for all citizens of the SFRY. Brotherhood and unity were cherished as the highest ideals in the context of Marxist education and upbringing of the 
children in the primary and secondary schools. In fact, the entirety of the Yugoslav socialist moral was based on this idea.

\section{Conclusion}

Someone could say that the idea of religious other was overcome with the collapse of the idea of brotherhood and unity of the peoples in Tito's Yugoslavia, that this model of cooperation of different ethnic and religious groups is gone. Some of the radical thinkers would say that maybe one of the reasons that Tito and his League of Communists smothered religious belonging and participation was the wish to stop any kind of religious intolerance and hate in the SFRY. Some could say that today's idea of religious and ethnic tolerance is just a logical continuation of the idea of brotherhood and unity, as a kind of neo-socialism. Nevertheless, today's situation is not any better than it was in the time of socialism. Consequently, what we're looking for is nothing but parallelism. If we think in this way, that means that we do not believe in the values and the meaning of one of the capital values of civilization, tolerance. The SFRY needs to be understood as a structural unit with different religions cultures and systems. The attitude and culture towards the other as world's richness and towards everything in it as a universal human experience was formed. That means that the attitude that the richness of diversity of human social experience is a requirement for its vitality and creativity was affirmed.

Thirdly, Macedonia, in the context of Tito's Yugoslavia in recent history, marked an advancement of the socialist project that had little room for publicly expressed religiousness and its free practicing, while the church, which was legally separate from the state, in reality positioned itself on "that" side of official society. The socialist state first nationalized church property which drastically decreased the economic power of the Macedonian Orthodox Church. Then it undertook a series of activities to minimize and marginalize the church. However, we need to emphasize the fact that the "Yugoslav case" is very different from the rest of the countries of real socialism or communism (the USSR, Romania, Albania, Bulgaria, etc.). In addition, we need to highlight several facts about the Socialist Republic of Macedonia as a part of the SFRY. Priests had seats in the first assemblies of national liberation during the Second World War. Furthermore, during that dark communist period, called so by the church, in 1945, the Ohrid Archbishopric was restored as a Macedonian independent church. Even more importantly, in 1967, the autocephality of the Macedonian Orthodox Church as the successor to the Ohrid Archbishopric was declared. In addition, in this period, the Socialist Republic of Macedonia not only did not close and destroy church buildings, but on the contrary, gave significant funding for their restoration (for instance, the most beautiful and impressive church ceilings of the Macedonian Orthodox Church were built during this time). In fact, this comes from the fact that the state perceived the church as a form of cultural heritage, which was a very important element in portraying the country to the world. This contributed to the preservation of the traditional values of the Macedonian people. During the time of the SFRY, the process of secularization of society was also characteristic. Consequently, in SR Macedonia it led to a decrease in the number of declared and true believers. This was followed by the eroding of religious practice, the dissolution of the dogmatic content of faith and a decrease in the influence of the church and Orthodox religiousness in the everyday life of the people. 
In the end, we will conclude with an answer to the question we asked in the beginning of this sociological analysis. From the three types of personal identification (ethnic, religious and civil), the civil identification was the most prominent in the citizens of the SFRY. This is complete identification through belonging to a state and its symbols, such as the flag, national anthem, national emblem etc. All this contributed to the long-lasting successful functioning of a society which was above nations and in which no state religion existed, and all religious communities were equally respected. Despite the breakdown of the SFRY, it will remain an example of a successful functioning of both religious and ethnic tolerance through the ideals of brotherhood and unity of all its peoples and nationalities. 
Зоран Д. Матевски ${ }^{1}$

Универзитет „Свети Ћирило и Методије” у Скопљу,

Филозофски факултет, Институт за социологију

Скопље (Република Македонија)

Душка Н. Матевска

Универзитет „Свети Ћирило и Методије” у Скопљу,

Факултет за педагогију

Скопље (Република Македонија)

\title{
ЕТНИЧКИ И РЕЛИГИЈСКИ ИДЕНТИТЕТИ У СОЦИЈАЛИСТИЧКОЈ ФЕДЕРАТИВНОЈ РЕПУЛИЦИ ЈУГОСЛАВИЈИ
}

\author{
(Превоg In Extenso)
}

Апстракт: Социјализам као политички систем, утемељен на врховној власти партије, који се ослања на колективизам, покушао је да избрише све разлике између друштвених група у СФРЈ. Марксистичка идеологија је имала у начелу негативан став према религији, што је довело до слабљења религозног идентитета становништва Југославије. С друге стране, стварање Југославије, у великом делу је ометало развој етничког идентитета. Стога је државни идентитет максимално појачан међу грађанима СФРЈ. Тако је формирано једно наднационално друштво без државне религије. Тиме су практично примењени принципи етничке и религиозне толеранције, ослањајући се на братство и јединство народа и народности, као на највиши идеал.

Кључне речи: етнички идентитет; религијски идентитет; државни идентитет

\section{Увод}

У друштвеном систему Социјалистичке Федеративне Републике Југославије постојало је пуно етничких група које су биле повезане судбином и носиле собом елементе заједничког живота. Југоловенске нације и етничке групе имале су заједничке победе и поразе у многим значајним моментима своје историје. Стога су развиле култ у смеру заједничких предака. Поред тога, посебно у контексту хришћанства, имали су много заједничких светаца, којима су се молили и славили их заједно. То је за ове различите религијске и етничке идентитете деловало као облик снажне духовне кичме у моментима друштвених криза. Пошто су живели у истој земљи, имали су исту политичку судбину. Ово је створило етничке и религијске колективе са заједничком историјом, што је имало снажан утицај на јачање осећања заједничког порекла. То понекад придоноси последњој и одлучујућој

\footnotetext{
1 matev@mt.net.mk

2 dmatevska@hotmail.com
} 
нити припадања националној свести (Weber, 1963). Па ипак, упркос свему овоме, ове етничке заједнице су задржале властити национални идентитет. Чињеница да су биле уједињене у својој борби против фашистичког режима је сигурно утицала на оно што им је заједничко. Следствено томе, живели су заједно дуго времена у истом политичком систему и створили су и применили комунистички систем, који се разликовао од других у контексту да је то био социјалистички комунистички систем, који се пак разликовао у контексту социјалистичког самоуправљања (Giddens, 2007).

Да бисмо све ово разумели, потребно је да истакнемо одређене културне и политичке одлике југословенске државе. Са историјске тачке гледања, Југославија је била оптерећена ауторитарном политичком културом. Снажна и дуготрајна доминација страних сила и империја (као што су Отоманска имерија, Аустроугарска империја итд.) обележила је све политичке етничке и религијске догађаје и односе. Грађани СФРЈ су живели у добу означеном сукобом ауторитарне политичке културе, с једне стране, и социјалистичке политичке културе, с друге. Начин на који су се религијски и етнички односи у СФРЈ одвијали у великој мери су зависили од исхода ове епохалне колизије. Показатељ паралелног постојања ових елемената ауторитарне и социјалистичке политичке културе је изузетно значајан у генези ових односа, који ће се касније преобразити у крвави отворени сукоб током разарања Југослвије. Бивше југословенске републике су доста хетерогене у етничком, религијском и културном смислу (Ćebić, 1988). У свој овој разноврсности, не би требало да потценимо религијски моменат, који је дубоко укорењен, има традицију и дели становништво у одвојене религијске групе. Наиме, у традицији сва три региона бивше Југославије (православља, католицизма и ислама) почивање је на елементима ауторитарног деловања. Све је ово имало утицаја на друштво као целину.

Друштвени идентитет имплицира групну самокласификацију и самоидентификацију појединца, са одређеним стереотипима других религијских и етничких група који се од њих разликују. Израз колективни идентитет је тесно повезан са нестанком личности и индивидуалности у већим структурама. Свака индивидуа покушава да створи његову или њену личну идентификацију. Без ње они се осећају изгубљенима у простору и времену. Постоје разни механизми личне идентификације. За потребе ове анализе, ми ћемо се усредсредити на три, по нашем мишљењу најзначајнија механизма личне идентификације. То су етничка, религизна и национална (грађанска) лична идентификација. Сви ови механизми личне самоидентификације не могу да имају подједнак интензитет. Јачање једног подразумева слабљење других. Питање на које ћемо покушати да одговоримо јесте који је механизам личне идентификације био најзначајнији и најинтензивнији међу грађанима СФРЈ?

\section{Етнички идентитет у СФРЈ}

Различите етничке и религијске групе у СФРЈ су увек осећале потребу да се диференцирају у односу на друге. Одговарајући на питање идентитета, појединци су тежили да пронађу на основу чега се разликују од религијског и етничког другог. Идентитет је тесно повезан са осећањем безбедности, поверења и припадања 
одређеној религијској или етничкој групи. Међутим, тежња ка отелотворењу и очувању овог идентитета подстакла је грађане СФРЈ у одређеним ситуацијама да делују ирационално и понекад чак насилно. У условима етничко-религијске разноврсности, у покушају да одговоре на питање припадања, појединци су се прво везали уз своје етничко и верско порекло. У етнички мешовитим срединама, идентитет појединца је великим делом повезан са припадништвом језику, култури и религији одређених заједница. Етнички идентитет, више него било који други идентитет, јесте производ примарне социјализације. Од раног детињства, појединци уче разлике између „нас” и „њих” и да не прихватају тако лако било шта што долази од „њих”. Овај процес може да се одвија спонтано и мирно, али такође може да му уследи напетост и сукоб, особито када „они” наметну свој идентитет „нама”. Ова напета ситуација представља један од главних разлога појаве етнонационализма у СФРЈ. То је доктрина коју етничка група поставља као циљ за сваку политичку активност, а етнички идентитет као меру сваке људске вредности. Етнонационализам постаје моћ која привлачи појединце и групе зато што је то доктрина која је оснажена етничким митовима, херојима и заједничком судбином. У оним појединцима и групама у којима етнички и религијски идентитет није оптерећен етнонационализмом, он представља културну традицију која није вршила притисак нити ограничавала. С друге стране, за одређене политичке структуре и елите у СФРЈ, ентонационализам је у основи представљао начин манипулације који ће на крају довести до распада Југославије.

У то време, идентитет је јачао процес уједињења личног и колективног, представљајући начин проналажења сопственог идентитета у контексту колективног. С обзиром на то да особа припада различитим друштвеним групама које дефинишу њен идентитет, идентитет је задобијао различите групне и колективне димензије. Лична димензија колективног идентитета омогућила је да се легитимно говори и делује у контексту нације и религије. Национални идентитети су утемељени на заједничким митовима и историјским сећањима, заједничкој масовној кутлури, заједничким правима и дужностима за све чланове заједничке привреде, уз територијалну мобилност њених припадника (Smith, 1991, str. 14). Упркос спољашњим функцијама националног идентитета, успостављене су његове бројне унутрашње функције, као што су то социјализација појединаца као чланова националног ентитета и грађана СФРЈ.

Етнонационализам у СФРЈ се манифестовао као претерана зависност појединаца од своје нације и њених интереса, занемарујући интересе других нација који су у одређеним историјским и друштвеним контекстима били детерминисани као пријатељски, а у другим непријатељски. Појављивао се као облик националне свести која је стално наглашавала разлике између властите и других нација, представљајући властиту нацију као супериорну у односу на све друге нације. То је довело до изражавања предрасуда у односу на друге етничке групе и до сумње у њих. Паралелно са овим се дешавало стално потцењивање културних творевина и одлика других нација у непосредном окружењу. Свако је тежио да оствари привилегован положај у контексту југословенске федерације (Žunic, 2008).

Инструментализација етничког идентитета кроз етнонационализам манифестовала се кроз многе етничке сукобе у СФРЈ током седамдесетих и осамдесетих го- 
дина. Она је сигурно била додатно ојачана процесима економске, политичке и културне глобализације. У то време, полако али сигурно, започет је процес преласка са једног модела уређења и друштвено-колективистичке парадигме (социјализма) на потпуно другачији модел, као што је политички плурализам у контексту либералног капитализма. Све ово је довело до новог друштвено-интерактивног обрасца понашања у оквиру којеа се етнонационализам наметнуо као извор мобилизације и хомогенизације. Овај процес је нажалост потиснуо претходну политику братства и јединства која је била симбол етничке и верске толеранције. Подстицање етнонационализма и националне искључивости је превладало идеју коегзистенције различитих етничких група, која је била доминантна друштвена вредност у претходном периоду и темељ мирног разрешавања етнчких и верских сукоба и њихове контроле.

Један од главних разлога за сукобе у СФРЈ деведесетих година била је манипулација националног питања, у којој су различита друштвена, економска, културна и политичка питања преображена у проблеме усредсређене око националног, што је представљало етнизацију политичког и политизацију етничког питања. Овај етнонационалистички дискурс је био утемељен на историјској прошлости, обичајима и усменој традицији. Основни и најзначајнији идентитет у етнонационализму је етнички идентитет. Он је одређен, наслеђен и не може да се промени. Етнички идентитет великим делом одређује друге идентитете. Изнад свега, он одређује религијски идентитет. Један од основних проблема у вези са етнонационализомом у СФРЈ било је преплитање етничког и религијског идентитета. Да би дефинисале властити идентитет, етничке групе на територији бивше СФРЈ су користиле културне одлике, симболе и митове присутне у великом броју у религијама православаца, католика и муслимана. Из овог разлога, по правилу, етнички Срби, Македонци и Црногорци, у великој већини, изјашњавали су се као православци, док се већина етничких Хрвата и Словенаца изјашњавала као католици. Чак и велики део атеиста није био искључен из овог правила (Bogomilova, 2005).

Процес преклапања ислама са етницитетом је јединствен и занимљив. Током пописа југословенског становништва 1948, становништво Босне и Херцеговине је добило 3 могућности с обзиром на националност: муслиман-Србин, муслиманХрват и муслиман са неодређеном националношћу. Резултат је био тај да је 25.000 одабрало муслиман-Хрват, 72.000 муслиман-Србин и 778.000 је изјавило да је неодређене националности. Попис из 1953. је последњи који је поставио питање у вези са религијом. Тада се на нивоу Југославије $12,5 \%$ становништва изјаснило као муслимани. У то време израз муслиман је имао само религијско значење. У контексту идеје да се установи категорија Југословена као једног етницитета, у попису се појавила категорија муслиман-неодређене националности. У Босни и Херцеговини се 891.000 становника тако изјаснило. Током пописа 1971, израз Муслиман је поново задобио националну конотацију (Malcolm, 1994). Због овог, највећи део становништва које се изјаснило као етнички Југословени живело је и радило у Босни и Херцеговини.

За разлику од других делова СФРЈ, у Босни и Херцеговини етнички и религијски муслимани се поклапају, зато што једино овде они представљају једну етнонационалну категорију. Чињеница је да чак и пре исламизације, становништво Босне и Херцеговине није имало јединствен српски или хрватски идентитет. Уколико 
процењујемо сложену верско-кутурну и историјску легитимност босанских муслимана, они су изразили јасан захтев за етничким идентитетом који се разликује од Срба и Хрвата. Они су се идентификовали као припадници формиране муслиманске културе која је прихваћена пре више векова, више или мање добровољно у својству Словена под отоманском упрвом. Поред тога, људи који су били отуђени од муслиманске заједнице и нису практиковали муслиманску веру такође су се придружили муслиманској националности.

Муслимани су почели све чешће да одређују властити етнонационални идентитет и да се изјашњавају као Бошњаци у националном смислу. Овим су политичке елите Босне и Херцговине желеле да докажу да је постојао босанско-херцеговачки народ, т.j. бошњачка етничка група, која се разликује од српске и хрватске етничке гурпе. Легитимизација бошњачког идентитета је наметнула озбиљно питање које између осталог само илуструје сложену културну традицију СФРЈ. Да ли се одређење Бошњак односи на све становнике Босне и Херцеговине или само на муслимане? У којем су односу Бошњаци и остали исламизовани Словени у СФРЈ, као што су македонски муслимани у Македонији? Ово јасно показује да у етничкокултурној мешавини у СФРЈ није било јасних етничких решења.

\section{Религијски идентитет у СФРЈ}

Геополитички положај СФРЈ је био такав да је чак и за време тзв. Велике шизме у једанаестом веку граница између византијске - источне и римске - западне цркве ишла кроз територију СФРЈ. Ситуација се из основа променила, постајући све сложенија, у петнаестом веку, када је велики део територија које су касније постале део СФРЈ анектиран од стране тада моћне Отоманске империје. Од тада, три различита типа цивилизације су ишла заједно са три типа религије: католицизмом, православљем и исламом. На територији СФРЈ, три небеска краљевства (католицизам, православље и ислам) долазе у контакт и преплићу се. Стога, то постаје бојно поље три велике кутуре и цивилизације. Европа, посебно на почетку средњег века, била је обликована древним аутентичним вредностима јудаизма, хришћанства и ислама. Недалеко одатле, у Македонији, Бугарској и Босни и Херцеговини, тајне групе богумила су већ вековима биле активне у тим регионима. Све ове религије су у својој сржи врло сличне једна другој, зато што потичу од јудаизма као своје заједничке древне основе. Поред тога, све оне проповедају мир као свој идеал. Упркос томе, СФРЈ је била суочена са међурелигијским расправама које су се касније претвориле у крваве сукобе током разарања СФРЈ, кроз грубу и беспоштедну злоупотребу верских осећања грађана СФРЈ.

Ово, пре свега, резултира из суштине великих монотеистичких религија које су се појавиле из аврамске традиције. У својој сржи, оне су врло нетолерантне. Оне имају утврђене и непроменљиве погледе на свет, стриктан етички кодекс и повлаче јасну границу између оних који јесу и оних који нису истински верници. За њихове догме и правила се каже да су дате од бога и да представљају вечну истину. Оне не могу да буду предмет преговарања, компромиса или уступака. Када је једна таква група суочена са другом сличном групом, оне неминовно проглашавају једна другу за пагане, јеретике и отпаднике. Оне нису у стању да признају једна другој удео у 
сазнавању истине. Када би то учиниле, то би бацило сумњу на њихове властите догме. Када верници ове три религије дођу у контакт, обично завршавају у сукобу. Ове религије су истовремено веома колективистичке. Оне тврде да њихови верници представљају специјалну и морално супериорну заједницу. Повезаност са њима лако постаје знак етничке или националне лојалности. Највећа опасност лежи у вези између нације и религије. Поред тога, уколико би аврамске религије постале фактор у политици, довеле би до сталних сукоба са религијским другим због својих бескомпромисних погледа (Hеywood, 2009).

Сада, у контексту теме, говорићемо о односу између религије и нације. На почетку, треба да истакнемо да религија и нација непобитно представљају две моћне форме припадања и идентификације. Оне су моћни механизми кроз које личност трага за властитим идентитетом. Међутим, ове две форме идентитета не могу да имају подједнак интензитет ни у једном тренутку. Да би се оснажило национално осећање, религијско осећање треба да буде ослабљено и обратно. Већина социолошких истраживања у овом домену указује на занимљив податак. Религија и нација нису логички повезане. Поред овога, чињеница је да је вера једна универзална категорија изнад нације. Међутим, упркос овим непобитним чињеницама, ове две друштвене појаве су у једној неуништивој психолошкој вези и тајној унији. Религијска нетолерантност је нарочито повишена у време етничких сукоба. Само тада вера и нација постају иста ствар. У свим другим периодима мира, то није случај (Ramet, 2008).

Из свега овога можемо да закључимо да су народ и нација историјске чињенице, док је вера изнад историје и једна есхатолошка категорија. За религију, и цркву као њену институцију, најзначајнија је особа или верник, док је за нацију најважнији дух припадања. Ако покушамо да направимо одређену дистинкцију између нације и религије, можемо да кажемо да, темпорално говорећи, религија долази пре нације. Постојање религије је повезано са самом појавом људи, док нације постоје само последња два века. Друго, религија је важнији критеријум класификације од нације зато што је уопштенији. Ако желите да истакнете да је неко добра особа, рећи ћете да је он или она добар хришћанин или добар муслиман. Израз „добар верник” указује на морално савршену особу. Треће, са етичког становништа, религија је изнад нације. Религија је етичка категорија, док је нација етничка категорија. Ми ћемо закључити овај део исказом да једнакост религијских институција и група пружа боље шансе за кохезију и интеграцију друштвене заједнице (Davie, 2017). Слично, идеја о формирању једне државне религије смањује шансе да сви сегменти друштвеног живота буду интегрисани. Следствено, ми бисмо могли да тврдимо да у СФРЈ никада нису постојали верски сукоби, него само етнички конфликти подстицани политичким циљевима.

Најбољи начин да се установи религијска и етничка толеранција као и идеја екуменизма и неоекуменизма, јесте стварање над-националног друштва. У овом над-националном друштву, једини критеријум је држављанство. У том типу друштва, људске вредности постају општије. Уопштавање вредности и норми доводи до формирања универзалних људских права и вредности. Са овим долази до пада наслеђених етничких права и пратећих обичаја, моралних норми и претпоставки. Универзалне вредности и норме, као пратећа људска права и слободе, примењују се 
на целокупно становништво датог друштва, што није случај у етничким заједницама. Све је ово било утврђено у СФРЈ кроз идеју братства и јединства. Систем вредности и норми је био издигнут на универзални ниво. Случај СФРЈ потврђује да, слично као што постоји процес одвајања цркве и државе, постоји и процес одвајања држављанства од националности.

Појава религијског другог, т.ј другости, постала је највиши приоритет за социјалистичко југословенско друштво. Комунистичка политичка елита СФРЈ није могла да занемари овај феномен, а још мање да га игнорише. Братство и јединство као политичка идеологија била је базирана на идеји да грађани СФРЈ треба да поштују једни друге упркос њиховој религији или етницитету. У мултиетничким и мултиконфесионалним срединама сваке аутономне републике и покрајине СФРЈ, људи су подучавани да комуницирају и живе једни са другима. Кроз идеју братства и јединства, људи су подучавани да религијски идентитет других њих ни на који начин не угрожава, већ напротив, само обогаћује и њихов властити религијски идентитет. Југословенска федерација је преживела зато што су, сви подједнако, упркос религији и етницитету стварали систем социјалистичког самоуправљања. Све остало су биле предрасуде које за време одређених периода развоја југословенског социјалистичког друштва нису могле да буду превазиђене, или су биле непотребно наглашаване. Све ово је довело то етничких и верских сукоба, нарочито током разарања Југославије.

Идеолошка и политичка елита социјалистичког политичког система у СФРЈ је знала да је религијска другост врло осетљива појава. Са теоријске тачке гледишта, етничка и религијска другост је конститутивна категорија, т.j. проблем узајамног деловања између два народа, између два становишта, или проблем духовно-темпоралне комуникације између две или више култура, као што је с правом нагласио један од највећих савремених антрополога и социолога Клод Леви-Строс (Claude Lévi-Strauss). Овај феномен етничког и религијског другог је изричито уткан у најосетљивије сфере друштвеног живота, у образовање, политику и масовне медије. Деца су у свим образовним институцијама свих република и покрајина СФРЈ учила о практичним користима поштовања етничког и религијског другог.

У овој анализи ми покушавамо да објаснимо проблем затворености малих органских култура. Када говоримо о СФРЈ, ми говоримо о култури која је увек била у сукобу и суочена са потенцијалним неспоразумима. Евентуални конфликти су решавани путем „еуфорије затворености”, поделом субјеката на „нас” и „њих”, тако да је унапред познато ко припада којој групи. Овај тип културе се предаје властитој херметичности, стварајући илузију да све што није „наше” није природно. Наша анализа чињеничног статуса свих типова другости заступљених у образовању, политици и масовним медијима у СФРЈ нуди аргументе који доказују да неповерење, затовреност и изолационизам нису били само неприродни за југословенско социјалистичко друштво, него су били потпуно недостижни као егизстенцијалне категорије у широј сфери свакодневног живота. Све ово је остварено кроз практичну примену принципа етничке и верске толеранције, изражених кроз идеју братства и јединства између свих народа и етничких група СФРЈ.

У друштвеном развоју СФРЈ, принципи толераниције су дуго били прихваћени под тзв. моделом заједничког живота различитих заједница са различитим култу- 
рама и религијама. У СФРЈ било је више религијских заједница и религијских група које су показивале интересовање за одржавањем и гајењем сопственог културног и историјског наслеђа. То је било изражено у облику отпора према оном што је „страно и није моје” или оном што припада „њима” а не „нама”. Следствено, поставило се питање развоја свести и методологије која би учинила дељење религијског наслеђа на целокупној територији СФРЈ могућим. Представљање другог, његово или њено именовање и препознавање од стране друге религијске групе зависи од угла гледања субјекта. На пример, за православног хришћанина друго представља муслиман, католик, протестант или члан било којег новог религијског покрета.

Све што су кроз векове створиле различите културе и цивилизације на територији југословенске федерације не треба да буде негирано, већ поштовано, објективно третирано и проучавано и прихваћено као заједничко културно наслеђе. Питања која су постављана у овом контексту била су третирана озбиљно и Комунистичка партија Југославије је расправљала о њима. Многи конгреси и пленуми које је организовала КПЈ били су посвећани развоју принципа етничке и верске толеранције, изражених кроз идеју братства и јединства за све грађане СФРЈ. Братство и јединство били су цењени као највиши идеал у контексту марксистичког образовања и одгоја деце у основним и средњим школама. У ствари, целина југословенског социјалистичког морала је била утемељена на овој идеји.

\section{Закључак}

Неко би могао да каже да је идеја религијског другог постала превазиђена са колапсом идеје братства и јединства народа у Титовој Југославији, да је тај модел сарадње различитих етничких и религијских група нестао. Неки од радикалних мислилаца би казали да је можда један од разлога што су Тито и Савез комуниста пригушивали религијску припадност и партиципацију била жеља да прекину сваку врсту религијске нетолеранције и мржње у СФРЈ. Неки би могли да кажу да данашња идеја религијске и етничке толеранције представља само логични продужетак идеје братства и јединства, као једне врсте неосоцијализма. Међутим, данашња ситуација није ништа боља него што је била у време социјализма. Стога, оно за чиме трагамо је само паралелизам. Ако мислимо на овај начин, то значи да ми не верујемо у вредност и значење једне од капиталних вредности цивилизације, толеранцију. СФРЈ треба разумети као структуралну јединицу са различитим религијским културама и системима. Однос и култура према различитом као благу света и према свему што га чини као универзално људско искуство, били су формирани. То значи да је био потврђен став да је поштовање различитости људског друштвеног искуства услов за његову виталност и креативност.

Треће, Македонија је у контексту Титове Југославије у недавној историји означила напредак социјалистичког пројекта који је имао мало простора за јавно изражену религиозност и њено слободно практиковање, док је црква, која је правно одвојена од државе, у стварности себе позиционирала на „тој” страни званичног друштва. Социјалистичка држава је прво национализвала црквену својину што је драстично смањило економску моћ Македонске православне цркве. Тада је социјалистичка држава предузела серију делатности да умањи и маргинализује 
цркву. Међутим, треба да нагласимо чињеницу да је „југословенски случај” веома различит од остатка земаља реалног социјализма или комунизма (СССР, Румунија, Албанија, Бугарска итд.). Поред тога, треба да истакнемо неколико чињеница о Социјалистичкој Републици Македонији као делу СФРЈ. Попови су имали седишта у првим скупштинама националног ослобођења за време Другог светског рата. Штавише, у оном, како га је црква назвала, тамном комунистичком периоду 1945. године, Охридска архиепископија је обновљена као македонска независна црква. Још значајније, 1967. године декларисана је аутокефалност Македонске православне цркве као наследнице Охридске архиепископије. Поред тога, у овом периоду СРМ не само да није затворила и уништила црквене зграде, него је, напротив, давала значајне финансије за њихову рестаурацију (на пример, најлепше и најимпресивније црквене таванице у МПЦ су изграђене током овог времена). У ствари, ово долази из чињенице да је држава посматрала цркву као облик културног наслеђа који је био врло важан елемент у представљању земље свету. То је допринело очувању традиционалних вредности македонског народа. За време СФРЈ, такође је био карактеристичан процес секуларизације друштва. Стога је у СР Македонији дошло до смањивања броја изјашњених и правих верника. То је било праћено ерозијом религијске праксе, разједињењем догматског садржаја вере и смањењем утицаја цркве и православне религиозности на свакодневни живот народа.

На крају, закључићемо одговором на питање које смо поставили на почетку ове социолошке анализе. Од три типа личне идентификације (етничке, религијске и државне), државна идентификација је била најизраженија међу становницима СФРЈ. То је комплетна идентификација кроз припадање држави и њеним симболима, као што је застава, национална химна, национални амблеми итд. Све ово је допринело дуготрајном успешном функционисању наднационалног друштва у коме није постојала државна религија и све религијске заједнице су биле подједнако поштоване. Упркос распаду СФРЈ, она ће остати пример успешног функционисања како религијске тако и етничке толеранције кроз идеале братства и јединства свих њених народа и народности. 


\section{REFERENCES / ЛИTЕРATУPA}

Bogomilova, N. (2005). Religion, Law and Politics in the Balkans at the end of the $20^{\text {th }}$ and early $21^{\text {st }}$ centuries. Sofia: Istok - Zapad. [In Bulgarian].

Davie, G. (2017). Religion in Public Life: Levelling the Ground. London: Theos

Giddens, A. (2007). Sociology. Zagreb: Nakladni zavod Globus.

Heywood, E. (2009). Politics. Skopje: Akademski pecat. [In Macedonian].

Malcolm, N. (1994). Bosnia: A Short History. New York: New York University Press.

Ramet, S. (2008). The Three Yugoslavias: State - Building and Legitimation, 1918 - 2005. Bloomington: Indiana University Press.

Smith, A. (1991). National Identity. London: Penguin Books Ltd.

Weber, M. (1963). The sociology of religion. Boston: Beacon Press.

Ćebić. P. (1988). Ecumenism and Religious Tolerance in Yugoslavia. Beograd: NIRO Mladost. [in Croatian].

Žunić, D. (2008). Nation and Nationalism. Niš : Odbor za građansku inicijativu. [In Serbian]

Превод на српски / Translation into Serbian

др Вера Вратуша / Vera Vratuša PhD 